\title{
NEW RECORDS OF GRIFFIN'S LEAF-NOSED BAT (Hipposideros griffini Thong et al. 2012) FROM VIETNAM
}

\author{
Vu Dinh Thong \\ Institute of Ecology and Biological Resources, VAST, thong@iebr.ac.vn
}

\begin{abstract}
Griffin's Leaf-nosed bat (Hipposideros griffini) is one of the largest species of the family Hipposiderodae. In the field, it is recognisable from other hipposiderid species of Vietnam by body size, noseleaf structure, and echolocation frequency. Prior to this study, Hipposideros griffini was only known from two national parks (Cat Ba and Chu Mom Ray) in Vietnam. This paper provides new data recorded from Cat Tien national park, Southern Vietnam, indicating a more extensive distribution of Hipposideros griffini. Results from previous and current studies indicate that Griffin's Leaf-nosed bat inhabits in various habitats ranging from flat/lowlands to offshore islands, mountainous and karst areas.
\end{abstract}

Keywords: Mammalia, Chiroptera, Hipposideridae, Hipposideros, bat, echolocation, taxonomy.

\section{INTRODUCTION}

The genus Hipposideros currently consists of 71 species worldwide, including 16 species occurred in Vietnam $[3,7,8,9,10]$. The recent discovery of Griffin's Leaf-nosed bat from Vietnam has received special attention from both the public and scientific media. The original description was based on specimens from two disjunct locations: Cat $\mathrm{Ba}$ and $\mathrm{Chu}$ Mom Ray National Parks [9]. Additional records included here extend both the distribution and range of habitats utilised by this species.

\section{MATERIAL AND METHODS}

\section{Specimens examined}

A total of 13 individuals were collected from a capture site $\left(11^{\circ} 28^{\prime} \mathrm{N}, 107^{\circ} 23^{\prime} \mathrm{E} ; 148\right.$ meters above sea level) within the core zone of Cat Tien National Park (CTNP) by the author and his colleague from the Institute of Ecology and Biological Resources (IEBR), Hanoi, Vietnam. They are all adults and were retained as study specimens ( 9 males: IEBR-T.2012.01.09 and 4 females: IEBR-T.2012.10-.13) in the Department of Zoological Museum of IEBR. Comparative material examined comprise the holotype (IEBR-T.200809.12), paratypes (IEBR-T.200809.1; IEBR-T.200809.9) and a referred specimen IEBR-T.270608.6. Data from these comparative materials were not included in the following section "results and discussion". IEBR-T. refers to Vu Dinh Thong collection deposited at IEBR.

\section{Bat capture and measurements}

Bat capture methods and morphometric measurements taken were as per $\mathrm{Vu}$ Dinh Thong et al. (2012) and Vu Dinh Thong et al. (2012) $[9,10]$. In the field, bats were captured using four-bank harp traps [6] and mist nets of various sizes (2.6 m [height], 3-12 m [length], mesh size: $16 \mathrm{~mm} \times 16 \mathrm{~mm}$ ). Captured bats were removed carefully from the trap or net and placed individually in a cotton bag. External measurements taken in the field were FA, forearm length: from the extremity of the elbow to the extremity of the carpus with the wings folded; EH, ear height: length of ear conch; EW, ear width: the greatest width of ear conch; ANW, anterior noseleaf width: the greatest width of the anterior leaf; TIB, tibia length: from the knee joint to the ankle; HF, hind-foot length: from the extremity of the heel behind the os calcis to the extremity of the longest digit, excluding the hairs or claws.

Skulls of eight study specimens were extracted and cleaned for the following craniodental measurements: SL, total length of skull: from occiput to the most anterior part of the canine; CCL, condylocanine length: from the exoccipital condyle to the most anterior part of the canine; RW, rostrum width: measured in front of the anterior ramus of the anteorbital bar; IOW, interorbital width: the least width of the interorbital constriction; $\mathrm{ZW}$, zygomatic 
width: the greatest width of the skull across the zygomatic arches; MW, mastoid width: the greatest distance across the mastoid region; $\mathrm{C} 1-$ $\mathrm{C} 1$, upper canine width: greatest width, taken across the outer borders of upper canines; M3M3, upper molar width:greatest width, taken across the outer crowns of the last upper molars; C1-M3, maxillary toothrow length: from the front of upper canine to the back of the crown of the third molar; C1-P4, upper caninepremolar length: from the front of the upper canine to the back of the crown of the posterior premolar; $\mathrm{ml}$, mandible length: from the anterior rim of the alveolus of the first lower incisor to the most posterior part of the condyle; c1-m3, mandibular toothrow length: from the front of the lower canine to the back of the crown of the third lower molar; c1-p4, lower canine-premolar length: from the front of the lower canine to the back of the crown of the posterior premolar. The above measurements were taken using a digital caliper to the nearest $0.1 \mathrm{~mm}$, and they are illustrated in Bates and Harrison (1997) and Csorba et al. (2003) [1, 5]. Ages were assessed following Brunet-Rossinni and Wilkinson (2009) [4]. Data from all juveniles were excluded from analyses.

\section{Sound recording and analysis}

Echolocation recordings were obtained in three situations inside a flight-tent: handheld $(\mathrm{H})$, resting $(\mathrm{R})$ on the wall and flying $(\mathrm{F})$ using a PCTape system at a sampling rate of $480 \mathrm{kHz}$.
Batman software was used to obtain high quality sound sequences. All echolocation signals were analysed using Selena software to measure the constant frequency of the second harmonic $\left(\mathrm{CF}_{2}\right)$ of each call. The PCTape system, Batman and Selena softwares are custom-made by the University of Tübingen, Germany.

\section{RESULTS AND DISCUSSION}

Griffin's Leaf-nosed bat is a very large species of Hipposideros. All external and craniodental features of 13 individuals exhibit the typical characteristics of Hipposideros griffini. Externally, their FA and $\mathrm{EH}$ are in a range of 83.0-90.5 $\mathrm{mm}$ and 27.0-30.3, respectively (table 1). There are four distinct pairs of supplementary lateral leaflets (fig. 1). EW is in range of 22.6$26.8 \mathrm{~mm}$ (table 1). Their skulls are large with a greatest length of 28.6-30.3 mm (table 2) and a rounded posterior emargination of the palate (fig. 2 ). The first upper premolar is minute and situated outside the toothrow. Upper and lower toothrow lengths are 11.1-11.8 and 12.2-13.0 $\mathrm{mm}$, respectively (table 2 ). The $\mathrm{CF}_{2}$ values of the examined individuals in handheld, resting, and flying situations are 75.3-79.5 kHz, 76.3-78.3 $\mathrm{kHz}$ and $76.0-77.9 \mathrm{kHz}(\mathrm{n}=13)$, respectively (table 1). Detailed measurements are given in Table 1 and Table 2. Other features of these individuals mostly fit the characteristics of Hipposideros griffini described in $\mathrm{Vu}$ Dinh Thong et al. (2012) [9].

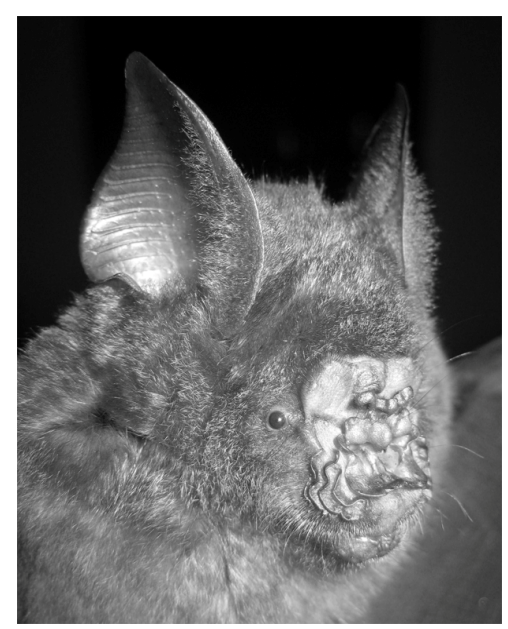

Figure 1. Ear and nose-leaves of Hipposideros griffini. Photo: Vu Dinh Thong 


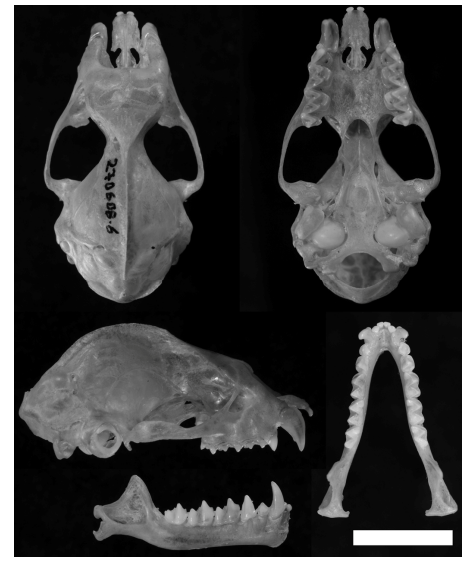

Figure 2. Dorsal, ventral and lateral (from top-left clockwise) views of the skull and mandible of Hipposideros griffini (IEBR-T.270608.6). Scale $=10 \mathrm{~mm}$. Photo: Vu Dinh Thong

Table 1. External measurements (in $\mathrm{mm}$ ) and echolocation frequency (in $\mathrm{kHz}$ ) of Hipposideros griffini

\begin{tabular}{|c|c|c|}
\hline \multirow{2}{*}{ Measurements } & \multicolumn{2}{|c|}{ Sex } \\
\hline & $q q(n=4)$ & $\hat{\sigma}{ }^{\lambda}(n=9)$ \\
\hline \multirow{2}{*}{ FA } & $84.9 \pm 2.4$ & $87.0 \pm 2.2$ \\
\hline & $83.0-88.3$ & $83.2-90.5$ \\
\hline \multirow{2}{*}{$\mathrm{EH}$} & $28.3 \pm 1.0$ & $29.2 \pm 0.7$ \\
\hline & $27.0-29.5$ & $28.2-30.3$ \\
\hline \multirow[b]{2}{*}{ EW } & $24.7 \pm 0.5$ & $24.4 \pm 1.3$ \\
\hline & $24.0-25.2$ & $22.6-26.8$ \\
\hline \multirow[b]{2}{*}{ ANW } & $8.8 \pm 0.5$ & $8.4 \pm 1.2$ \\
\hline & $8.2-9.4$ & $6.8-10.2$ \\
\hline \multirow{2}{*}{ TIB } & $35.1 \pm 0.3$ & $37.7 \pm 1.6$ \\
\hline & $34.8-35.5$ & $36.2-40.5$ \\
\hline \multirow{2}{*}{$\mathrm{HF}$} & $15.3 \pm 0.7$ & $15.0 \pm 0.7$ \\
\hline & $14.5-16.0$ & $14.0-16.0$ \\
\hline \multirow[b]{2}{*}{$\mathrm{F}$} & $77.5 \pm 0.7$ & $77.0 \pm 0.7$ \\
\hline & $76.5-78.0$ & $76.0-77.9$ \\
\hline \multirow{2}{*}{$\mathrm{H}$} & $77.3 \pm 0.6$ & $77.3 \pm 1.2$ \\
\hline & $76.6-77.9$ & $75.3-79.5$ \\
\hline \multirow{2}{*}{$\mathrm{R}$} & $77.4 \pm 0.7$ & $77.4 \pm 0.6$ \\
\hline & $76.5-78.3$ & $76.3-78.2$ \\
\hline
\end{tabular}

Values are given as mean $\pm \mathrm{SD}$, minimum-maximum. Abbreviations are defined in the Material and Methods.

Previous records of $H$. griffini and $H$. armiger in two adjacent capture sites within Cat $\mathrm{Ba}$ National Park suggested that these two species may forage in the same habitats. However, there was no record of $H$. armiger at the capture site during our surveys in CTNP. Borissenko and Ivanova (unpublished report) [2] recorded $H$. armiger from CTNP without reference to either morphometrics or echolocation frequencies. $\mathrm{Vu}$ Dinh Thong et al. (2012) [9] indicated that nose leaf structures and many morphological characteristics of $H$. griffini are similar to those of $H$. armiger. Extensive examinations of materials collected by Borissenko and Ivanova are required to solidly confirm the distribution of $H$. armiger in CTNP. 
Table 2. Craniodental measurements (in mm) of Hipposideros griffini

\begin{tabular}{|c|c|c|}
\hline \multirow{2}{*}{ Measurements } & \multicolumn{2}{|c|}{ Sex } \\
\hline & 웅 $(n=4)$ & ठิ \\
\hline \multirow{2}{*}{ SL } & $29.2 \pm 0.3$ & $29.7 \pm 0.5$ \\
\hline & $28.8-29.5$ & $28.6-30.3$ \\
\hline \multirow{2}{*}{ CCL } & $25.7 \pm 0.3$ & $26.0 \pm 0.4$ \\
\hline & $25.3-26.0$ & $25.3-26.8$ \\
\hline \multirow{2}{*}{ RW } & $8.6 \pm 0.2$ & $8.9 \pm 0.3$ \\
\hline & $8.3-8.8$ & $8.5-9.4$ \\
\hline \multirow{2}{*}{ IOW } & $3.8 \pm 0.3$ & $4.1-0.3$ \\
\hline & $3.5-4.2$ & $3.6-4.5$ \\
\hline \multirow{2}{*}{ ZW } & $16.5 \pm 0.2$ & $16.5 \pm 0.3$ \\
\hline & $16.2-16.8$ & $16.0-17.0$ \\
\hline \multirow{2}{*}{ MW } & $13.9 \pm 0.3$ & $14.3 \pm 0.3$ \\
\hline & $13.5-14.3$ & $13.8-14.8$ \\
\hline \multirow{2}{*}{$\mathrm{C} 1-\mathrm{C} 1$} & $7.5 \pm 0.3$ & $7.7 \pm 0.3$ \\
\hline & $7.1-7.7$ & $7.1-8.0$ \\
\hline \multirow{2}{*}{ M3-M3 } & $11.2 \pm 0.2$ & $11.4 \pm 0.2$ \\
\hline & $11.0-11.5$ & $11.0-11.8$ \\
\hline \multirow{2}{*}{ C1-M3 } & $11.4 \pm 0.2$ & $11.5 \pm 0.2$ \\
\hline & $11.2-11.6$ & $11.1-11.8$ \\
\hline \multirow{2}{*}{ C1-P4 } & $5.4 \pm 0.4$ & $5.4 \pm 0.3$ \\
\hline & $5.0-6.0$ & $5.0-6.0$ \\
\hline \multirow[b]{2}{*}{$\mathrm{ml}$} & $20.2 \pm 0.5$ & $20.5 \pm 0.5$ \\
\hline & $19.5-20.6$ & $19.8-21.5$ \\
\hline \multirow{2}{*}{$\mathrm{c} 1-\mathrm{m} 3$} & $12.6 \pm 0.3$ & $12.6 \pm 0.2$ \\
\hline & $12.2-13.0$ & $12.2-13.0$ \\
\hline \multirow{2}{*}{ c1-p4 } & $4.7 \pm 0.2$ & $4.7 \pm 0.1$ \\
\hline & $4.5-5.0$ & $4.5-5.0$ \\
\hline
\end{tabular}

Values are given as mean $\pm \mathrm{SD}$, minimum-maximum. Abbreviations are defined in the Material and Methods.

Results from observation in the field suggest that Hipposideros griffini is a cave-dwelling species. The capture site in CTNP is situated in a low and flat land region of Southern Vietnam. It is close to Dong Nai river, the second largest river in the southern section of the country. Forests covering the site are mostly primary in structure. These records strongly support a suggestion in Vu Dinh Thong et al. (2012) [9] that Griffin's Leaf-nosed bat may live in other areas of Vietnam and adjacent countries within the mainland Southeast Asia. Other bat species, which were recorded at the same site, included $H$. cineraceus, $H$. larvatus, $H$. cf. pomona, Rhinolophus chaseni, R. pusillus and Myoyis rosseti.
Acknowledgments: I would like to express my sincere thanks to the management board, Scientific Council, and Department of Zoological Museum of IEBR and CTNP for their administrative and financial supports to field surveys. Particular thanks are extended to P.D. Tien (IEBR), G. A. Hoye, M. Hoye, P. Spark, D. Spark (Australia), J. Hansford (Zoological Society of London) for their invaluable advice and comments on the manuscript; to H.-U. Schnitzler, A. Denzinger, C. Dietz, I. Dietz, and other staff at the Institute of Neurobiology, Faculty of Sciences, University of Tuebingen (UT), Germany; N.M. Furey (Fauna and Flora International, Cambodia); P. J. J. Bates, D. Harrison, M. Pearch, B. Lanzinger-Bates, N. 
Thomas of the Harrison Institute, England; P. A. Racey of the Aberdeen University, UK; A. Borissenko of the University of Guelph, Canada; and T. Kingston of the Texas Tech University, USA for their various support.

\section{REFERENCES}

1. Bates P. J. J., Harrison D. L., 1997. Bats of the Indian Subcontinent. Harrison Zoological Museum, Sevenoaks, Kent, United Kingdom, 297 pp.

2. Borissenko A. V., Ivanova N. V., (Unpublished report). Ecological studies of bats (Mammalia: Chiroptera) in Cat Tien National Park: 43 pp.

3. Borissenko A. V., Kruskop S. V., 2003. Bats of Vietnam and Adjacent Territories: an identification manual. Joint RussianVietnamese Science and Technological Tropical Centre, Moscow and Hanoi, Russia and Vietnam, 212 pp.

4. Brunet-Rossinni A. K. Wilkinson G. S., 2009. Methods for age estimation and the study of senescence in bats. In: Kunz T.H., Parsons S. (eds.) Ecological and Behavioral Methods for the Study of Bats, 2nd edition, Johns Hopkins University Press, Baltimore, pp. 315-325.

5. Csorba G., Ujhelyi P., Thomas N., 2003.
Horseshoe Bats of the World (Chiroptera: Rhinolophidae). Alana Books, England.

6. Francis C. M., 1989. A comparison of mist nets and two types of harp traps for capturing bats. Journal of Mammalogy, 70: 865-870.

7. Hendrichsen D. K., Bates P. J. J., Hayes B. D., Walson J. L., 2001. Recent records of bats (Mammalia: Chiroptera) from Vietnam with six species new to the country. Myotis 39: 35-199.

8. Vu Dinh Thong, 2011. Systematics and echolocation of rhinolophoid bats (Mammalia: Chiroptera) in Vietnam. PhD Thesis, University of Tuebingen, Tuebingen, Germany, 258 pp.

9. $\mathrm{Vu}$ Dinh Thong, Puechmaille S. J., Denzinger A., Dietz C., Csorba G., Bates P. J. J., Teeling E. C., Schnitzler H. U., 2012. A new species of Hipposideros (Chiroptera: Hipposideridae) from Vietnam. Journal of Mammalogy, 93: 1-11.

10. Vu Dinh Thong, Puechmaille S. J., Denzinger A., Bates P. J. J., Dietz C., Csorba G., Soisook P., Teeling E. C., Matsumura S., Furey N., Schnitzler H. U., 2012. Systematics of the Hipposideros turpis complex and a description of a new subspecies from Vietnam. Mammal Rev., 42: 166-192.

\section{GHI NHẬN MỚI VỀ LOÀI DƠI NẾP MŨI GRIP-PHIN (Hipposideros griffini Thong et al. 2012) Ở VIẸTT NAM}

\section{Vũ Đình Thống}

Viện Sinh thái và Tài nguyên sinh vật

\section{TÓM TẮT}

Dơi nếp mũi Grip-phin (Hipposideros griffini) là một trong những loài dơi có kích cỡ lớn nhất trong họ dơi nếp mũi Hipposideridae. Trên thực địa, loài dơi này có thể phân biệt với các loài dơi nếp mũi khác của Việt Nam bởi kích cỡ cơ thể, cấu trúc phần phụ mũi và tần số siêu âm. Trước nghiên cứu này, Hipposideros griffini mới chỉ được phát hiện ở hai vườn quốc gia (Cát Bà và Chư Mom Ray) của Việt Nam. Bài báo này cung cấp những dẫn liệu mới ghi nhận được ở vườn quốc gia Cát Tiên, miền Nam Việt Nam và mở rộng phạm vi phân bố của loài dơi này. Đáng chú ý, kết quả ghi nhận được từ nghiên cứu này và những công trình nghiên cứu trước cho thấy Dơi nếp mũi Grip-phin sinh sống ở nhiều sinh cảnh khác nhau: từ vùng đất thấp, bằng phẳng đến khu vực núi đất, hải đảo và vùng núi đá vôi.

Tù̀ khóa: Mammalia, Chiroptera, Hipposideridae, Hipposideros, dơi, siêu âm, phân loại.

Ngày nhận bài: 16-4-2012 